\title{
Chemical components separation with the use of Botulinum toxin A: a critical review for correction of ventral hernia
}

\author{
Gustavo Heluani Antunes de Mesquita', Yuri Justi Jardim, ${ }^{1,2}$, Diego Ramos Martines ${ }^{1}$, Leando

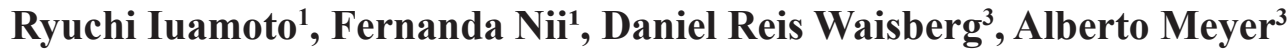

Mesquita GHA, Jardim YJ, Martines DR, Iuamoto LR, Nii F, Waisberg DR, Meyer A. Chemical components separation with the use of Botulinum toxin A: a critical review for correction of ventral hernia. Rev Med (São Paulo). 2018 Nov-Dec;97(6):569-73.

\begin{abstract}
Background: Ventral hernias are prevalent results in abdominal surgeries and may represent a surgical challenge in complex cases, mainly due to tension in abdominal wall musculature. Failure of surgical correction may lead to a more morbid treatment, in addition to a considerable socioeconomic impact. In order to have a lower risk of complications, the use of botulinum toxin A (BTA), may be a preoperative alternative to reduce abdominal wall tension by causing sustained and reversible paralysis. This critical review of the literature proposes to evaluate the adjacent use of BTA in surgical ventral hernias corrections. Methods: Using the PubMed database, the keywords 'ventral hernia', and 'botulinum toxin' were searched using the Boolean operator AND. Articles were selected based on their relevance and updated information. The outcomes of interest included the change in ventral hernia defect width and in lateral abdominal wall muscle length, pain, hernia recurrence and complications. Results: A total of 20 articles from 2009 to 2018 were found. We excluded some articles due to irrelevant technique, use of animal models and lack of outcome data. Reduction of the abdominal wall thickness increasing its length, less perioperative pain, hernia reduction and the correction with less tension were observed after the use of BTA injection. No complications occurred during applications. Conclusion: The use of BTA seems to be a promising alternative in the management of ventral hernias due to its capacity of reducing tension in the abdominal wall. However, more studies are necessary to determine the efficacy of this method.
\end{abstract}

Keywords: Botulinum toxin, type A; Herniorrhaphy; Abdominal wall/surgery; Ventral hernia; Incisional hernia.
RESUMO: Introdução: Hérnias ventrais são um resultado prevalente de cirurgias abdominais que podem representar um desafio cirúrgico em casos complexos, principalmente devido à tensão na musculatura da parede abdominal. A falha na correção cirúrgica pode levar a necessidade de um tratamento mais mórbido, além de um considerável impacto socioeconômico. Para que o risco de complicações seja menor, o uso da toxina botulínica A (TBA) pode ser uma alternativa pré-operatória para reduzir a tensão da parede abdominal, através de uma paralisia sustentada e reversível. Esta revisão crítica da literatura propõe avaliar o uso adjacente de TBA em correções de hérnias ventrais cirúrgicas. Métodos: Usando o banco de dados PubMed, as palavras-chave "ventral hernia" e "botullinum toxin" foram pesquisadas usando o operador "AND". Os artigos foram selecionados com base em sua relevância e informações atualizadas. Os desfechos de interesse incluíram a mudança na largura do defeito da hérnia ventral e no comprimento do músculo da parede abdominal lateral, dor, recidiva de hérnia e complicações. Resultados: Foram encontrados 20 artigos de 2009 a 2018. Foram excluídos artigos devido à técnica irrelevante, uso de modelos animais e falta de dados sobre resultados. Redução da espessura da parede abdominal aumentando seu comprimento, menos dor perioperatória, redução de hérnia e correção com menos tensão foram observados após o uso da injeção de BTA. Nenhuma complicação ocorreu durante as aplicações. Conclusão: O uso de TBA parece ser uma alternativa promissora no manejo de hérnias ventrais devido à sua capacidade de reduzir a tensão na parede abdominal. No entanto, mais estudos são necessários para determinar a eficácia deste método.

Descritores: Toxinas botulínicas tipo A; Herniorrafia: Parede abdominal/cirurgia; Hernia ventral; Hernia incisional.

Trabalho realizado na Faculdade de Medicina da Universidade de São Paulo, apresentado no XXXVII COMU, na categoria Monograph Awards.

1. Faculdade de Medicina FMUSP, Universidade de São Paulo. ORCID: Mesquita GHA - https://orcid.org/0000-0002-2334-6894; Martines DR - https://orcid.org/0000-0003-0559-1324; Iuamoto LR - https://orcid.org/0000-0002-6624-5815; Nii F - https://orcid. org/0000-0002-5254-4785.

2. Program in Global Surgery and Social Change, Department of Global Health and Social Medicine, Harvard Medical School, Boston, USA. https://orcid.org/0000-0001-9293-5310.

3. Departamento de Gastroenterologia, Hospital das Clínicas HCFMUSP, Faculdade de Medicina FMUSP, Universidade de São Paulo. ORCID: Waisberg DR - 0000-0003-4284-0633; Meyer A - https://orcid.org/0000-0002-8408-0508.

Correspondence: Gustavo Heluani Antunes de Mesquita. Email: gustavo.heluani@gmail.com. 


\section{INTRODUCTION}

Th abdominal surgery $28 \%$ of patients can develop ventral hernia ${ }^{1}$. In order to correct this hernia defects there are some techniques described such as anterior component separation (ACS), the posterior component separation (PCS), progressive preoperative pneumoperitoneum (PPP), mesh reinforcement, and optimal suturing techniques for large incisional hernias.

In this type of procedures, is frequent high recurrence rates, ranging from $12 \%-54 \%{ }^{2}$. Failure in the correction of hernia defect generates higher costs to the health care system, greater morbidity to the patient and more complexity in reconstructive surgical technique.

The success of surgical approach of the hernia depends on a variety of factors, such as the technique employed, the patient's comorbidities, and the size of the hernia defect. The European Hernia Society (EHS) establishes large incisional hernias (W3) according with the diameter of $10 \mathrm{~cm}$ or larger ${ }^{3}$. In these conditions, it's more difficult to repair without tension, which is fundamental for myofascial closure of the abdominal wall, what increases the risk of recurrence.

In this context, there are some techniques used to approach a first incisional hernia repair relieving tension. The ACS technique described by Ramirez et al. ${ }^{4}$ permits fascial repositioning through lateral stretching, restoring the integrity of the abdominal wall. However, we find in the literature significant rates of recurrence associated with this procedure. Another technique used is the PCS, which increases the size and assures fascial closure; and it was most recently described in the treatment of large ventral hernia defects ${ }^{5,6,7}$.

In more complex cases, these techniques alone are not sufficient to guarantee the closure of the hernia defect, with the appropriate tension. To achieve a lower risk of complications other techniques can be used, such as PPP and the placement of expanding tissues on the abdominal wall $^{6}$. Following the same principle, a recent proposal is the preoperative application of botulinum toxin A (BTA), a neurotoxic protein produced by Clostridium botulinum, for hernia correction, in order to relax and stretch the musculature.

BTA has been used in medical practice for treatment of a great variety of conditions. It's preoperative application, can induce a sustained and reversible flaccid muscular paralysis helping the closure of the abdominal wall, which should help to lower the recurrence rate $\mathrm{e}^{1,2,8}$.

Abdominal wall reconstruction may benefit of the use of Botox injections to help in the abdominal components separation. The objective of this study was to conduct a critical review of the literature on the use of BTA in the surgical correction of Ventral Hernia.

\section{METHODS}

\section{Eligibility criteria}

The study population was patients undergoing ventral hernia repair. The intervention was administration of BTA as an adjunct to surgical hernia repair. The primary quantitative outcomes of interest included the decrease in ventral hernia defect width and the increase in lateral abdominal wall muscle length following BTA injection. Secondary outcomes of interest included pain, hernia recurrence, complications, length of stay, and length of follow-up.

\section{Literature search}

This critical review of the literature was performed using the PubMed database to search for published articles to include studies evaluating the effects of Botox on ventral hernias. The keywords 'ventral hernia' and 'botulinum toxin' were searched using the Boolean operator AND.

\section{RESULTS}

A total of 20 articles from 2009 to 2018 were found. These articles were selected based on their relevance and updated information.

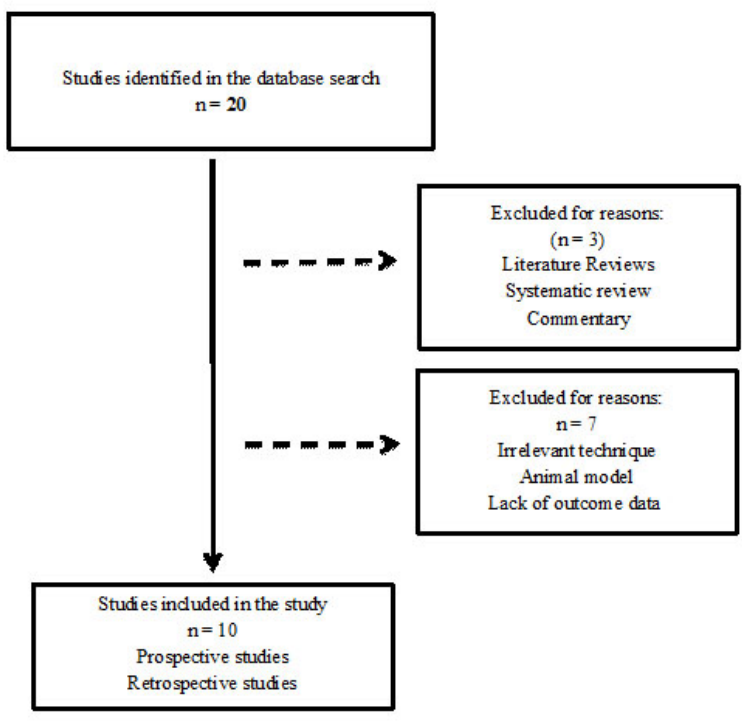

Figure 1 - Flow-diagram of studies included in the review 
Table 1. Included studies and characteristics

\begin{tabular}{|c|c|c|c|c|c|c|}
\hline Authors & Year & Design & $\begin{array}{l}\text { Number } \\
\text { of } \\
\text { patients }\end{array}$ & Primary outcome & Secondary outcome & BTA dosage \\
\hline $\begin{array}{l}\text { Zendejas } \\
\mathrm{B} \text {, et al. }\end{array}$ & 2013 & Retrospective & $\mathrm{n}=22$ & & $\begin{array}{l}\text { Patients used less analgesia } \\
\text { and reported less pain and, } \\
\text { there was no difference in } \\
\text { postoperative complications }\end{array}$ & 300 Units \\
\hline $\begin{array}{l}\text { Ibarra- } \\
\text { Hurtado } \\
\text { TR, et al. }\end{array}$ & 2014 & Prospective & $\mathrm{n}=17$ & $\begin{array}{l}\text { It was observed reduction in muscle } \\
\text { thickness and increase in muscle } \\
\text { length on both sides. Left muscle } \\
\text { thickness presented a mean reduction } \\
\text { of } 1 \pm 0.55 \mathrm{~cm}(\mathrm{p}<0.001) \text {. Right muscle } \\
\text { thickness presented a mean reduction } \\
\text { of } 1.00 \pm 0.49 \mathrm{~cm}(\mathrm{p}<0.001) \text {. Left muscle } \\
\text { length presented a mean increase of } \\
2.44 \pm 1.22 \mathrm{~cm}(\mathrm{p}<0.001) \text {. Right muscle } \\
\text { length presented a mean increase of } \\
2.59 \pm 1.38 \mathrm{~cm}(\mathrm{p}<0.001) \text {. }\end{array}$ & $\begin{array}{l}\text { No recurrences at mean } \\
\text { follow-up of } 49 \text { months were } \\
\text { observed }\end{array}$ & $\begin{array}{l}500 \text { units } \\
(250 \text { each } \\
\text { side) }\end{array}$ \\
\hline $\begin{array}{l}\text { Farooque } \\
\text { F, et al. }\end{array}$ & 2016 & Prospective & $\mathrm{n}=8$ & $\begin{array}{l}\text { Increase in mean length of lateral } \\
\text { abdominal wall from } 18.5 \mathrm{~cm} \text { pre-BTA } \\
\text { to } 21.3 \mathrm{~cm} \text { post-BTA }(\mathrm{P}=0.017) \text { with a } \\
\text { mean unstretched length gain of } 2.8 \mathrm{~cm} \\
\text { per side (range } 0.8-6.0 \mathrm{~cm}) .\end{array}$ & $\begin{array}{l}\text { All hernias were surgically } \\
\text { corrected with mesh with no } \\
\text { early recurrence. }\end{array}$ & 300 Units \\
\hline $\begin{array}{l}\text { Elstner KE, } \\
\text { et al. }\end{array}$ & 2016 & Prospective & $\mathrm{n}=27$ & $\begin{array}{l}\text { Increase in mean length of the lateral } \\
\text { abdominal wall from } 15.7 \mathrm{~cm} \text { pre-BTA } \\
\text { to } 19.9 \mathrm{~cm} \text { post-BTA }(\mathrm{p}<0.0001) \text {, with } \\
\text { mean unstretched length gain of } 4.2 \mathrm{~cm} / \\
\text { side (range } 0-11.7 \mathrm{~cm} / \mathrm{side})\end{array}$ & No early recurrences. & $\begin{array}{l}\text { Most patients } \\
\text { received a } \\
\text { total dose of } \\
300 \text { units }\end{array}$ \\
\hline $\begin{array}{l}\text { Ibarra- } \\
\text { Hurtado } \\
\text { TR, et al. }\end{array}$ & 2009 & Prospective & $\mathrm{n}=12$ & $\begin{array}{l}\text { Pre BTA mean defect width of } 13.9 \mathrm{~cm} \text {; } \\
\text { mean reduction was } 5.25 \mathrm{~cm}(\mathrm{p}<0.001) \text {. }\end{array}$ & $\begin{array}{l}\text { No recurrences at a mean } \\
\text { follow-up of } 9.08 \text { months. }\end{array}$ & $\begin{array}{l}500 \text { units } \\
(250 \text { each } \\
\text { side })\end{array}$ \\
\hline $\begin{array}{l}\text { Zielinski } \\
\text { MD, et al. }\end{array}$ & 2013 & Retrospective & $\mathrm{n}=18$ & $\begin{array}{l}\text { In this study, the rates of primary and } \\
\text { partial fascial closure were } 83 \% \text { and } \\
6 \% \text {, planned ventral hernia was } 11 \% \text {, } \\
\text { complications was } 67 \% \text {, and mortality } \\
\text { was } 11 \% \text {. }\end{array}$ & $\begin{array}{l}\text { Reported rates of } \\
\text { complications }(67 \%) \text {, and } \\
\text { mortality }(11 \%) \text {. }\end{array}$ & 300 units \\
\hline $\begin{array}{l}\text { Bueno- } \\
\text { Lledó J, } \\
\text { et al. }\end{array}$ & 2017 & Retrospective & $\mathrm{n}=45$ & $\begin{array}{l}\text { Was obtained an average value of } \\
\text { reduction of } 14 \% \text { of the volumes of } \\
\text { the incisional hernia (VIH)/abdominal } \\
\text { cavity (VAC) ratio after (PPP) and BTA } \\
(\mathrm{p}<0.05) \text {. }\end{array}$ & $\begin{array}{l}\text { No complications } \\
\text { occurred during the BT } \\
\text { administration. }\end{array}$ & 500 units \\
\hline $\begin{array}{l}\text { Elstner KE, } \\
\text { et al. }\end{array}$ & 2017 & Prospective & $\mathrm{n}=32$ & $\begin{array}{l}\text { Increase in mean baseline abdominal } \\
\text { wall length from } 16.4 \text { to } 20.4 \mathrm{~cm} \text { per side } \\
(\mathrm{p}<0.0001 \text { ) and the increase in mean } \\
\text { transverse length of the unstretched } \\
\text { anterolateral abdominal wall muscles of } \\
4.0 \mathrm{~cm} / \text { side (range } 0-11.7 \mathrm{~cm} / \mathrm{side} \text { ). }\end{array}$ & No hernia recurrences. & 300 Units \\
\hline $\begin{array}{l}\text { Rodriguez- } \\
\text { Acevedo } \\
\text { O, et al. }\end{array}$ & 2017 & Prospective & $\mathrm{n}=56$ & $\begin{array}{l}\text { In this study was obtained an increase in } \\
\text { mean lateral abdominal wall length from } \\
16.1 \mathrm{~cm} \text { to } 20.1 \mathrm{~cm} \text { per side, a mean gain } \\
\text { of } 4.0 \mathrm{~cm} / \mathrm{side} \text { (range } 1.0-11.7 \mathrm{~cm} / \mathrm{side} \text { ) } \\
\text { ( }<0.0001 \text { ), and the unstretched mean } \\
\text { length increase was } 8.0 \mathrm{~cm} \text { of the lateral } \\
\text { abdominal wall. }\end{array}$ & $\begin{array}{l}\text { One patient presented with a } \\
\text { new fascial defect } 26 \text { months } \\
\text { post-operative. }\end{array}$ & $\begin{array}{l}300 \text { or } \\
200 \text { units } \\
\text { depending on } \\
\text { the patient }\end{array}$ \\
\hline $\begin{array}{l}\text { Bueno- } \\
\text { Lledó J, } \\
\text { et al. }\end{array}$ & 2018 & Retrospective & $\mathrm{n}=70$ & $\begin{array}{l}\text { Mean reduction of } 16.6 \% \text { of the volumes } \\
\text { of the incisional hernia }(\mathrm{VIH}) / \text { abdominal } \\
\text { cavity (VAC) ratio after }(\mathrm{PPP}) \text { and BTA } \\
\text { was obtained }(\mathrm{p}<0.05) .\end{array}$ & $\begin{array}{l}\text { No complications } \\
\text { occurred during the BT } \\
\text { administration. }\end{array}$ & 500 Units \\
\hline
\end{tabular}




\section{DISCUSSION}

The incisional hernia is often common delayed complication following laparotomies surgeries. Some comorbidities such as diabetes, obesity, male sex, advanced age, incision type, immunosuppression therapy, wound infection and pulmonary complications are considered risk factors for incisional hernia development ${ }^{9,10}$. Closure of the abdominal wall with low tension with the use of mesh is the standard treatment for correcting this type of hernia ${ }^{5}$. Tension in the sutured area is commonly associated with ischemia in the abdominal wall, that can result in great probability of recurrence of the hernia defect. In large hernia cases, complementary techniques to stretch the abdominal wall are necessary in order to guarantee success of the surgical approach.

BTA is a therapeutic complementary treatment to decrease the suture tension and consequently the hernia recurrences rate. The flaccid muscular paralysis, provoked by this neurotoxin, takes effect from two days after application and lasts for 6-9 months ${ }^{10}$. It reduces the thickness of the abdominal wall, increasing its length, allowing hernia reduction and therefore allowing closure with less tension.

In a 2014 clinical trial of male trauma patients with hernia secondary to open abdomen management, Ibarra-Hurtado TR et al showed that left muscle thickness mean reduction was $1 \pm 0.55 \mathrm{~cm}(\mathrm{p}<0.001)$, right muscle thickness mean reduction was $1.00 \pm 0.49 \mathrm{~cm}(\mathrm{p}<0.001)$, left muscle length mean increase was $2.44 \pm 1.22 \mathrm{~cm} \mathrm{(p<}$ $0.001)$, and right muscle length mean increase was $2.59 \pm$ $1.38 \mathrm{~cm}(\mathrm{p}<0.001)^{1,11}$.

With a similar approach, Farooque et al. ${ }^{12}$ in a prospective pilot study in 2016, showed that post-BTA preoperative computed tomography showed a significant increase in mean length of lateral abdominal wall: $18.5 \mathrm{~cm}$ pre-BTA to $21.3 \mathrm{~cm}$ post-BTA $(\mathrm{P}=0.017)$ with a mean unstretched length gain of $2.8 \mathrm{~cm}$ per side (range 0.8 $6.0 \mathrm{~cm})^{12}$.

\section{REFERENCES}

1. Ibarra-Hurtado TR, Nuno-Guzman CM, Miranda-Diaz AG, et al. Effect of botulinum toxin type A in lateral abdominal wall muscles thickness and length of patients with midline incisional hernia secondary to open abdomen management. Hernia. 2014;18:647-52. doi: 10.1007/s10029-014-1280-2.

2. Weissler JM, Lanni MA, Tecce MG, Carney MJ, Shubinets V, Fischer JP. Chemical component separation: a systematic review and meta-analysis of botulinum toxin for management of ventral hernia. J Plast Surg Hand Surg. 2017;51(5):366-74. doi: 10.1080/2000656X.2017.1285783.

3. Muysoms FE, Miserez M, Berrevoet F, Campanelli G, Champault GG, Chelala E, et al. Classification of primary and incisional abdominal wall hernias. Hernia. 2009;13(4):407-14. doi: 10.1007/s10029-009-0518-x.
A 2016 prospective evaluation of 27 patients undergoing elective complex ventral hernia laparoscopic repair, conducted by Elstner et al. ${ }^{13}$, found similar positive results demonstrating an increase in mean length of the lateral abdominal wall from $15.7 \mathrm{~cm}$ pre-BTA to $19.9 \mathrm{~cm}$ post-BTA $(p<0.0001)$, with mean unstretched length gain of $4.2 \mathrm{~cm} /$ side (range $0-11.7 \mathrm{~cm} /$ side) $)^{13}$.

The injections of BTA minimizes the forces of traction on the area of closure during postoperative recuperation and the period of scarring of the operative wound. This promotes adequate perfusion to the area of the scarring, reducing postoperative morbidity, including pain, increasing the chances of successful primary closure of the incisional hernia ${ }^{14}$.

A systematic review and meta-analysis of botulinum toxin for management of ventral hernia done by Weissler et al. ${ }^{8}$ in 2017 , showed significant hernia width reduction (mean $=5.79 \mathrm{~cm} ; \mathrm{n}=29 ; \mathrm{p}<0.001)$ and lateral abdominal wall muscular lengthening $($ mean $=3.33 \mathrm{~cm} ; \mathrm{n}=44$; $\mathrm{p}<0.001$ ) following BTA applications ${ }^{8}$.

The advantage of the combination of abdominal wall reconstruction with the use of BTA is the minimal tension and protection of the sutures in the postoperative phase, what reduces the risk of recurrence, pain, and complications ${ }^{1,5,8,10-13,15-17}$.

\section{CONCLUSION}

A number of aspects of the closure of ventral incisional hernias remain controversial; among these is the use of botulinum toxin A. This paper describes a critical review, involving the application of BTA in the correction of ventral hernia defects. BTA seems to reduce the tension of the sutures in the postoperative phase, improving the patient's outcomes. But given the complexity of such cases, however, more studies are necessary to determine the efficacy of this method.

4. Ramirez OM, Ruas E, Dellon AL. Components separation method for closure of abdominal-wall defects: an anatomic and clinical study. Plast Reconstr Surg. 1990;86(3):519-26.

5. De Mesquita GHA, Iuamoto LR, Suguita FY, Essu FF, Oliveira LT, Torsani MB, Meyer A, Andraus W. Simple technique of subxiphoid hernia correction carries a low rate of early recurrence: a retrospective study. BMC Surg. 2017;17(1):51. doi: 10.1186/s12893-017-0249-3 .

6. Alam NN, Narang SK, Pathak S, Daniels IR, Smart NJ. Methods of abdominal wall expansion for repair of incisional herniae: a systematic review. Hernia. 2016;20(2):191-9. doi: 10.1007/s10029-016-1463-0.

7. Gibreel W, Sarr MG, Rosen M, Novitsky Y. Technical considerations in performing posterior component 
separation with transverse abdominis muscle release. Hernia. 20(3):449-59. doi: 10.1007/s10029-016-1473-y.

8. Zendejas B, Khasawneh MA, Srvantstyan B, Jenkins DH, Schiller HJ, Zielinski MD. Outcomes of chemical component paralysis using botulinum toxin for incisional hernia repairs. World J Surg. 2013;37(12):2830-7. doi: 10.1007/s00268-013-2211-6.

9. Weissler JM, Lanni MA, Tecce MG, Carney MJ, Shubinets V, Fischer JP. Chemical component separation: a systematic review and meta-analysis of botulinum toxin for management of ventral hernia. J Plast Surg Hand Surg. 2017;51(5):366-74. doi: 10.1080/2000656X.2017.1285783.

10. Torres L, Essu FF, De Mesquita GHA, Jardim YJ, et al. Component separation of abdominal wall with intraoperative botulinum A presents satisfactory outcomes in large incisional hernias: a case report. Int J Surg Case Rep. 2017;41:99-104. doi: 10.1016/j.jisscr.2017.09.037.

11. Ibarra-Hurtado TR, Nuno-Guzman CM, EcheagarayHerrera JE, et al. Use of botulinum toxin type a before abdominal wall hernia reconstruction. World J Surg. 2009;33(12):2553-6. doi: 10.1007/s00268-009-0203-3.

12. Farooque F, Jacombs AS, Roussos E, Read JW, Dardano AN, Edye M, et al. Preoperative abdominal muscle elongation with botulinum toxin A for complex incisional ventral hernia repair. ANZ J Surg. 2016;86(1-2):79-83. doi: 10.1111/ans.13258.

Received: October 11, 2018

Accepted: October 11, 2018
13. Elstner KE, Jacombs AS, Read JW, et al. Laparoscopic repair of complex ventral hernia facilitated by pre-operative chemical component relaxation using Botulinum Toxin A. Hernia. 2016;20(2):209-19. doi: 10.1007/s10029-0161478-6.

14. Zielinski MD, Goussous N, Schiller HJ, Jenkins D. Chemical components separation with botulinum toxin A: a novel technique to improve primary fascial closure rates of the open abdomen. Hernia. 2013;17(1):101-7. doi: 10.1007/ s10029-012-0995-1.

15. Bueno-Lledó J, Torregrosa A, Ballester N, Carreño O, Carbonell F, Pastor PG, Pamies J, Cortés V, Bonafé S, Iserte J. Preoperative progressive pneumoperitoneum and botulinum toxin type A in patients with large incisional hernia. Hernia. 2017;21(2):233-43. doi: 10.1007/s10029017-1582-2.

16. Elstner KE, Read JW, Rodriguez-Acevedo O, et al. Preoperative progressive pneumoperitoneum complementing chemical component relaxation in complex ventral hernia repair. Surg Endosc. 2017;31(4):1914-22. doi: 10.1007/s00464-016-5194-1.

17. Rodriguez-Acevedo O, Elstner KE, Jacombs ASW, Read JW, Martins RT, Arduini F, Wehrhahm M, Craft C, Cosman PH, Dardano AN, Ibrahim N. Preoperative Botulinum toxin A enabling defect closure and laparoscopic repair of complex ventral hernia. Surg Endosc. 2018;32(2):831-9. doi: 10.1007/s00464-017-5750-3. 